\title{
Notes on a population of Columella edentula (Gastropoda: Pulmonata: Truncatellinidae) at a sedge meadow in Western Poland
}

\author{
Zofia Książkiewicz-Parulska ${ }^{1}$ (D)
}

Received: 20 March 2019 / Accepted: 10 July 2019 / Published online: 31 July 2019

(C) The Author(s) 2019

\begin{abstract}
Columella edentula (Draparnaud, 1805) is a species of a minute land snail inhabiting moist habitats. Its biology and behavioral patterns are unrecognized. This study focuses on population dynamics of $C$. edentula and investigates the tendency of the species to climb up plants. The field researches were carried out at a moist sedge meadow in western Poland during two growing seasons (spring and summer of 2008 and 2009). The data analysis revealed differences in patterns of climbing behavior and population dynamics in the studied period.
\end{abstract}

Keywords Mollusca $\cdot$ Invertebrates $\cdot$ Population dynamic $\cdot$ Behaviour

\section{Introduction}

Columella edentula (Draparnaud, 1805) is a Holarctic minute land snail species (shell's height does not exceed $3 \mathrm{~mm}$, width $1.5 \mathrm{~mm}$ ) (Wiktor 2004) that inhabits moist environments on calcareous substrates (Welter-Schultes 2012). It occurs in well-vegetated habitats, mainly in undisturbed places such as wetlands, woodlands, and grasslands (Kerney 1999) where it occupies the least moist and not inundated microhabitats (Książkiewicz et al. 2013; Książkiewicz-Parulska and Ablett 2017). It may also be found in forests and alder swamps (Pokryszko 1990a; Welter-Schultes 2012).

The biology and behaviour of Columella edentula are poorly recognized. Based on the development of copulatory organs, three types of individuals may be distinguished in populations of the species: euphallic, aphallic and hemiphallic (Pokryszko 1987). Although both, self-fertilization and crossfertilization may occur, self-fertilization is probably more common for this truncatellid (see Pokryszko 1987). A study on the reproduction of $C$. edentula was done by Myzyk (2011), who recorded that in the laboratory the species laid

Zofia Książkiewicz-Parulska ksiazkiewicz@amu.edu.pl

1 Department of General Zoology, Faculty of Biology, Adam Mickiewicz University, Umultowska 89, 61-614 Poznań, Poland eggs in April while hatching in the wild (at a site in NW Poland) occurred in May and at the beginning of June. Pokryszko (1990a) reported that in summer the species was found on plants such as Asarium europaeum L., Glechoma hederacea L., Cirsium oleraceum (L.) but later it occupied leaf and plant litters.

This study is focused on population dynamics of C. edentula and the tendency of the species to climb up plants in relation to the time of the year (spring and summer) was investigated. Field researches were carried out at a moist sedge meadow in western Poland during two growing seasons in 2008 and 2009.

\section{Material and methods}

\section{Study site and data collection}

The study site is located in western Poland in a valley of a small lowland river $\left(52^{\circ} 20^{\prime} 09.7 \mathrm{~N} ; 15^{\circ} 03^{\prime} 07.3 \mathrm{E}\right.$; ca. 0.15 ha in area). The area was fairly open and densely covered by Carex acutiformis and Urtica dioica, the moss cover was poorly developed. Mean moisture level of the site in 2008 was $78.1 \%(\sigma=19.4)$ and in 2009 it was $77.3 \%(\sigma=15.8)$. Groundwater level varied from $-20 \mathrm{~cm}$ to $-5 \mathrm{~cm}$ during the study period, $\mathrm{pH} \approx 7.6$ (for a detailed description of the site, see Książkiewicz et al. 2013; Książkiewicz-Parulska and 
Ablett 2017). The meteorological conditions (mean temperature and total precipitation) in the study periods are given in Table 1 .

The field study was carried out during the spring and summer seasons of 2008 and 2009. Samples were collected six times each year (three times per season). In 2008 samples were collected on 23 May, 5 June, 30 June (spring) and 9 August, 30 August, 23 September (summer); the dates of material collection in 2009 were the following: 12 May, 2 June, 26 June (spring) and 3 August, 25 August, 13 September (summer). Samples were collected along four parallel transects at $10 \mathrm{~m}$ intervals using a $0.25 \times 0.25 \mathrm{~m}$ frame $\left(0.0625 \mathrm{~m}^{2}\right.$ in the area). Along all transects, four samples were collected each time. All loose litter and dead vegetation cut from the soil and root-mat was harvested to a depth of $5 \mathrm{~cm}$ and all vegetation to ground level was collected (Cameron 2003). In the laboratory, litter and soil samples were dried and divided into two fractions using a
$0.5 \mathrm{~mm}$ sieve. Particles passing through the sieve were checked manually for the presence of snails under a stereo microscope (for detailed methodology see Książkiewicz et al. 2013). The retained fraction and cut plants were carefully examined for snails using a magnifying glass. For further analyses, only data on the living individuals were used (snails extracted from samples were identified and classified either as alive or dead at the time of sampling based on shell wear and the presence or absence of a dried body, Cameron 1982).

To illustrate the population dynamics, snails were divided into juveniles and adults based on shell development. Individuals with a shell containing five whorls or less were classified as juveniles, and those with a greater number of whorls were classified as adults (Pokryszko 1987). Calculations of species' densities on particular days were based on all samples collected from the studied site in the given years.
Table 1 The mean temperature (Temp) and total precipitation (Prec) for two-week periods from April to September of 2008 and 2009

\begin{tabular}{|c|c|c|c|c|c|c|}
\hline Year & Period & Temp $\left[{ }^{\circ} \mathrm{C}\right]$ & Prec $[\mathrm{mm}]$ & Juv $\left[\mathrm{i} / 0.0625 \mathrm{~m}^{2}\right]$ & Adt $\left[\mathrm{i} / 0.0625 \mathrm{~m}^{2}\right]$ & Samp dat \\
\hline \multirow[t]{12}{*}{2008} & $1-15 \mathrm{IV}$ & 7.1 & 74.8 & & & \\
\hline & $16-30 \mathrm{IV}$ & 10.4 & 19.1 & & & \\
\hline & $1-15 \mathrm{~V}$ & 13.9 & 1.5 & & & \\
\hline & $16-31 \mathrm{~V}$ & 15.0 & 31.6 & 1.25 & 0.38 & $23 \mathrm{~V}$ \\
\hline & $1-15 \mathrm{VI}$ & 18.0 & 15.7 & 2.63 & 1.06 & $5 \mathrm{VI}$ \\
\hline & $16-30 \mathrm{VI}$ & 18.0 & 13.4 & 1.5 & 0.93 & $30 \mathrm{VI}$ \\
\hline & $1-15 \mathrm{VII}$ & 18.8 & 26.4 & & & \\
\hline & $16-31 \mathrm{VII}$ & 19.3 & 24.8 & & & \\
\hline & $1-15$ VIII & 19.8 & 31.3 & 1.5 & 0.63 & $9 \mathrm{VIII}$ \\
\hline & 16-31 VIII & 17.3 & 28.6 & 1.38 & 0.69 & $30 \mathrm{VIII}$ \\
\hline & $1-15$ IX & 15.7 & 32.2 & & & \\
\hline & 16-30 IX & 10.7 & 22.6 & 0.63 & 0.13 & $23 \mathrm{IX}$ \\
\hline \multirow[t]{12}{*}{2009} & $1-15 \mathrm{IV}$ & 11.9 & 4.6 & & & \\
\hline & $16-30 \mathrm{IV}$ & 12.8 & 6.3 & & & \\
\hline & $1-15 \mathrm{~V}$ & 12.2 & 13.3 & 0.87 & 0.33 & $12 \mathrm{~V}$ \\
\hline & $16-31 \mathrm{~V}$ & 14.8 & 88.8 & & & \\
\hline & $1-15 \mathrm{VI}$ & 14.0 & 49 & 0.44 & 0.50 & $2 \mathrm{VI}$ \\
\hline & $16-30 \mathrm{VI}$ & 16.8 & 24.9 & 0.38 & 0.13 & $30 \mathrm{VI}$ \\
\hline & $1-15 \mathrm{VII}$ & 19.4 & 138.9 & & & \\
\hline & 16-31 VII & 19.1 & 62.7 & & & \\
\hline & $1-15 \mathrm{VIII}$ & 19.1 & 10.6 & 0.56 & 0.19 & 9 VIII \\
\hline & 16-31 VIII & 18.9 & 12.2 & 0.93 & 0.14 & $30 \mathrm{VIII}$ \\
\hline & 1-15 IX & 15.9 & 18.0 & 0.75 & 0.13 & 13 IX \\
\hline & 16-30 IX & 13.4 & 10.6 & & & \\
\hline
\end{tabular}

In bold - the highest mean temperature in the year, in italics - the highest total precipitation (source: Institute of Meteorology and Water Management IMGW, National Research Institute; data from Stubice station). The Table also shows a mean number of juveniles (Juv) and adults (Adt) per $0.0625 \mathrm{~m}^{2}\left(\mathrm{i} / 0.0625 \mathrm{~m}^{2}\right.$ ) in samples collected on particular days (Samp dat) 


\section{Statistical analyses}

Due to lack of normality nonparametric methods were used for data analyses. The Wilcoxon signed-rank test for pairwise comparisons with a Monte Carlo permutation test (10000 permutations) was used to compare the number of individuals on plants and within the litter in the spring and summer of 2008 and 2009. To check if the percent of the individuals found on plants and within the litter differed between these seasons in both years, $\mathrm{Chi}^{2}$ test was used. For the mentioned calculations only those samples were used where C. edentula was detected (see Table 2). All statistical analyses were performed with the Past software.

\section{Results and discussion}

Different patterns of population dynamics were recorded in the two-year study period (Fig. 1). The maximum density of juveniles in 2008 was recorded in spring, on 5 June, what corresponds with observations presented by Myzyk (2011). A year later, in 2009, the maximum quantity of juveniles was recorded in the summer period, in August. In both years the peak in the number of the truncatellid was preceded by extensive precipitation what may suggest the role of the weather in shaping patterns of population dynamics (see also Pokryszko 1990b). The stimulating effect of the rainfall in land snails' reproduction was previously

Table 2 Dates of sample collection (date) and the total number of samples collected on particular days $(\mathrm{N})$ including the number of samples where $C$. edentula was present (NP), number of individuals in the litter $(\mathrm{CeL})$ and found on plants $(\mathrm{CeP})$

\begin{tabular}{llllll}
\hline Date & & N & NP & CeL & CeP \\
\hline 2008 & 23 May & 16 & 10 & 26 & 2 \\
& 5 June & 16 & 14 & 59 & 0 \\
& 30 June & 15 & 11 & 37 & 3 \\
& 9 August & 16 & 12 & 34 & 2 \\
& 30 August & 16 & 12 & 33 & 1 \\
& 23 September & 8 & 3 & 6 & 2 \\
Total & & 87 & 62 & 195 & 10 \\
2009 & 12 May & 15 & 8 & 18 & 0 \\
& 2 June & 16 & 9 & 15 & 2 \\
& 26 June & 16 & 5 & 8 & 5 \\
& 3 August & 16 & 6 & 12 & 13 \\
& 25 August & 14 & 8 & 15 & 8 \\
& 13 September & 16 & 8 & 14 & 5 \\
Total & & 93 & 44 & 82 & 33 \\
\hline
\end{tabular}

described in other species (e.g. Pollard 1975; Tompa 1984; Silva and Omenta 2014).

Comparing the two studied years, the lower mean number of C. edentula was recorded in 2009, when maximum oviposition probably occurred later in the growing season than in 2008. It could have resulted from generally less suitable environmental conditions for the species (i.e. affected by the weather) in the second year of the study. Similarly to the results presented by Cowie (1984) for Theba pisana (Müller, 1774) (the late season clutches were smaller than the early ones), I also speculate that $C$. edentula may have a tendency to deposit a smaller number of eggs later in a season. In simpler terms - under suitable conditions, a single individual lays more eggs earlier in a season than later in a season. The costly reproduction (in the case of minute land snails investment in egg production is high; see Baur 1989) in the period preceding winter may enhance mortality rate during hibernation (see e.g. in Nicolai et al. 2010). Additionally, these efforts may go to waste if juveniles do not achieve a critical shell size before hibernation and die in the winter time, which seems to be more likely for juveniles that hatched in late summer than for those that hatched in spring. It results from the high sensitivity of the young individuals of Vertigo to unfavourable environmental conditions (Pokryszko 1992).

The pattern of climbing behaviour at the studied site also varied between the years 2008 and 2009 (Fig. 2). The Wilcoxon signed-rank test showed that in spring and summer of 2008 more snails occurred within the litter than on plants (spring: $\mathrm{z}=5.113, p<0.001$; summer: $\mathrm{z}=4.251, p<0.001$ ) while results of $\mathrm{Chi}^{2}$ test were statistically insignificant $\left(\mathrm{Chi}^{2}=1.048, p=0.497\right)$. In the spring of 2009 significantly more snails were found within the litter $(\mathrm{z}=3.356, p<0.001)$ while in the summer the differences in the number of individuals found within the litter and on plants were statistically insignificant $(\mathrm{z}=1.745, p=0.089)$. The $\mathrm{Chi}^{2}$ test showed that the percentage of snails on plants and within the litter was statistically different between the spring and summer of $2009\left(\mathrm{Chi}^{2}=15.022, p<0.001\right)$. Thus individuals of C. edentula were usually more abundant within the litter than on plants during the studied period and only in the summer of 2009 the tendency for climbing was more pronounced. This way, the information provided by Pokryszko (1990a) on summer climbing of $C$. edentula was partially confirmed, as in some years, individuals of the species may be abundantly found on plants. The reason for such behaviour is unknown. It may be speculated that climbing up plants is related to the presence of predators (e.g. Saeki et al. 2017). The shell of C. edentula is devoid of apertural barriers which could enhance their protection against predators (Pokryszko 1997).

Also, microclimatic conditions near the ground may trigger the upwards migrations in search of more suitable 

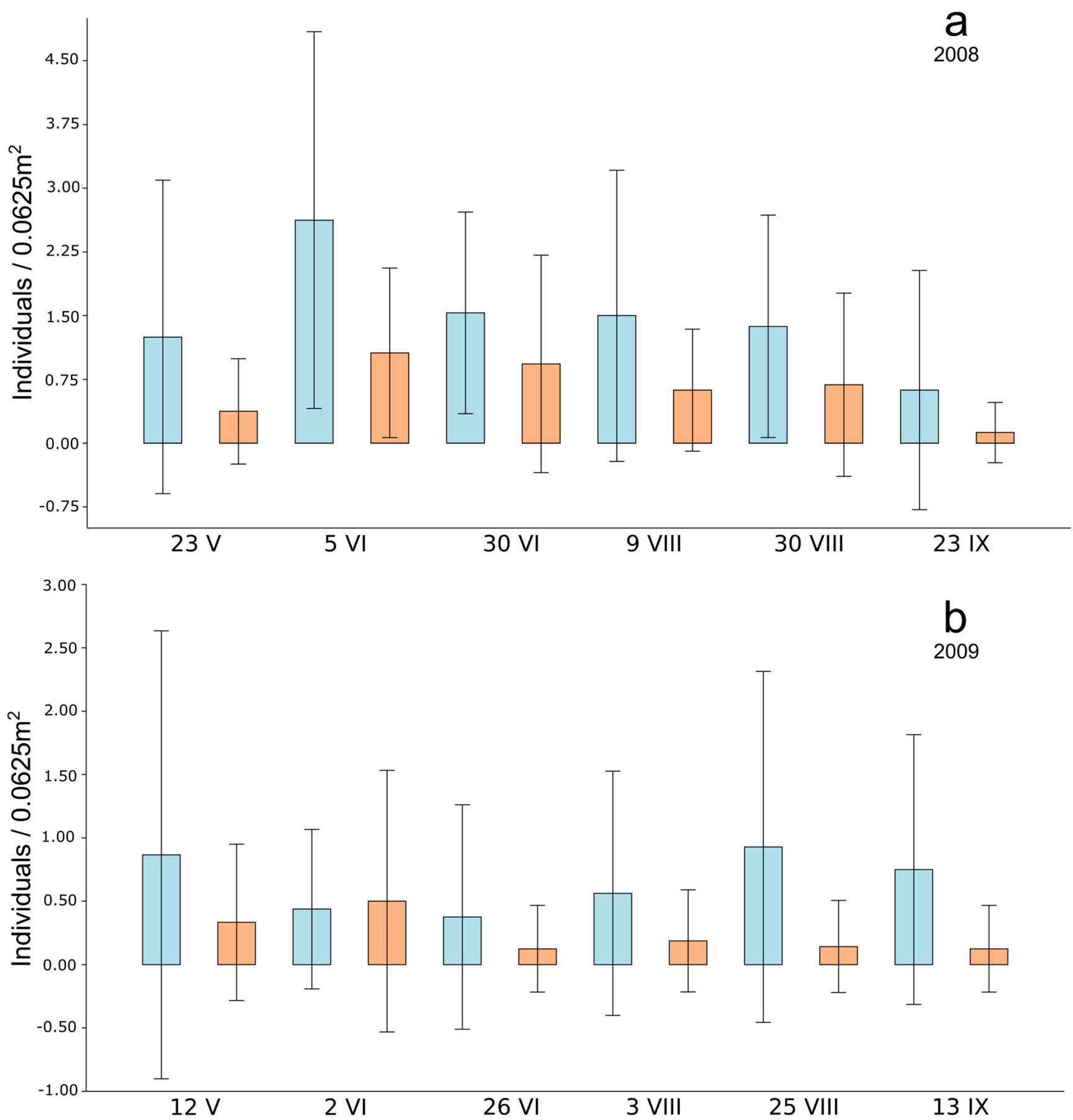

Fig. 1 Bar charts illustrating changes in the number of juveniles (blue bars) and adults (orange bars) in samples collected on particular days in 2008 (a) and 2009 (b) at the studied site; whiskers, standard deviation

conditions as it was shown for arid dwelling snail species (e.g. Cowie 1985). In such habitats, on sunny days, the surface of the ground and the adjacent air reach a higher temperature than the air above them (see in Cowie 1985). Comparing the weather in the summer of 2008 and 2009, the mean temperature was higher while the total precipitation was lower in 2009 (see Table 1). It might have contributed to the deterioration of microclimatic conditions near the ground and forced snails to climb up the plants. Such a situation most likely concerned the least moist microhabitats at margins of the studied site where vegetation was less compacted and individuals of 
Fig. 2 Box plots show data on the number of individuals of

C. edentula found within the litter (orange bars) and on plants (green bars) in spring and summer in 2008 (a) and 2009 (b); median horizontal line inside the box; whiskers - minimum and maximum values. All figures were generated in Past software and enhanced with InkScape software
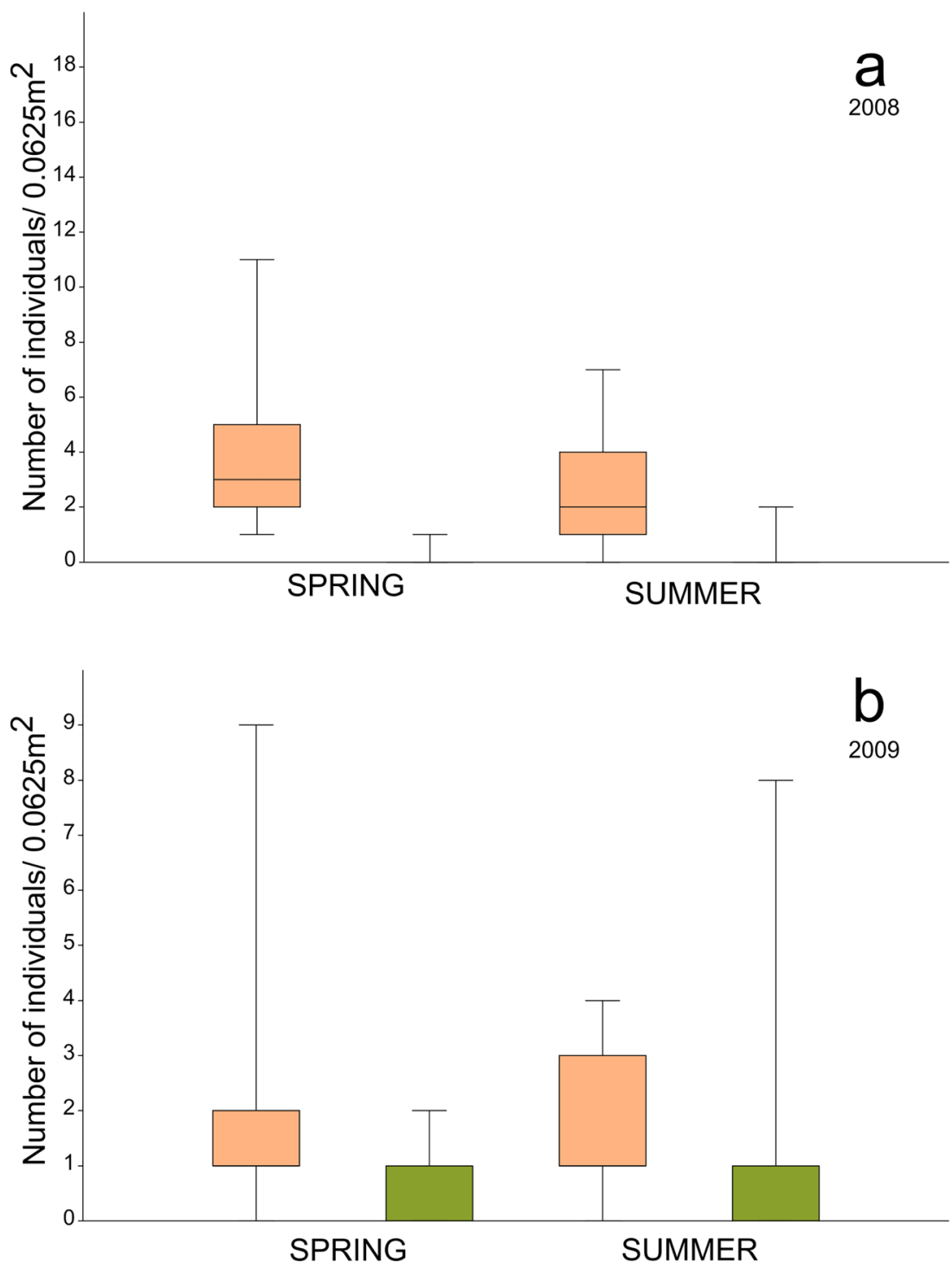

C. edentula were numerous (Książkiewicz et al. 2013; Compliance with ethical standards Książkiewicz-Parulska and Ablett 2017).

\section{Summary}

1. The differences in the pattern of Columella edentula population dynamics probably result from the weather conditions. The reproduction of the species seems to be related to the periods of high precipitation.

2. Individuals of the species may be found on plants and within the litter during a whole vegetative period but usually in greater numbers within the litter at the studied site.

3. The intensification of climbing behaviour may vary between the vegetative seasons and is probably related to weather and microhabitats occupied by the species.
Conflict of interest The author declares that she has no conflict of interest.

Open Access This article is distributed under the terms of the Creative Commons Attribution 4.0 International License (http:// creativecommons.org/licenses/by/4.0/), which permits unrestricted use, distribution, and reproduction in any medium, provided you give appropriate credit to the original author(s) and the source, provide a link to the Creative Commons license, and indicate if changes were made.

\section{References}

Baur B (1989) Growth and reproduction of the minute land snail Punctum pygmaeum (Draparnaud). J Mollus Stud 55:383-387. https://doi. org/10.1093/mollus/55.3.383

Cameron RAD (1982) Life histories, density and biomass in a woodland snail community. J Mollus Stud 48:159-166. https://doi.org/10. 1093/oxfordjournals.mollus.a065632 
Cameron RAD (2003) Life-cycles, molluscan and botanical associations of Vertigo angustior and Vertigo geyeri (Gastropoda, Pulmonata, Vertiginidae). Heldia 5:95-110

Cowie RH (1984) The life-cycle and productivity of the land snail Theba pisana (Mollusca: Helicidae). J Anim Ecol 53:311-325. https://doi. org/10.2307/4359

Cowie RH (1985) Microhabitat choice and high temperature tolerance in the land snail Theba pisana (Mollusca: Gastropoda). J Zool 207: 201-211. https://doi.org/10.1111/j.1469-7998.1985.tb04924.x

Kerney MP (1999) Atlas of the land and freshwater molluscs of Britain and Ireland. Harley Books, Great Horkesley, Essex

Książkiewicz Z, Kiaszewicz K, Gołdyn B (2013) Microhabitat requirements of five rare Vertiginid species (Gastropoda, Pulmonata: Vertiginidae) in wetlands of Western Poland. Malacologica 56:95106. https://doi.org/10.4002/040.056.0207

Książkiewicz-Parulska Z, Ablett JD (2017) Microspatial distribution of molluscs and response of species to litter moisture, water levels and eutrophication in moist, alkaline ecosystems. Belg J Zool 147:3753. https://doi.org/10.26496/bjz.2017.3

Myzyk S (2011) Contribution to the biology of ten vertiginid species. Folia Malacol 19:55-80. https://doi.org/10.2478/v10125-0110004-9

Nicolai A, Rouland-Lefèvre C, Ansart A, Filser J, Lenz R, Pando A, Charrier M (2010) Seasonally contrasting life-history strategies in the land snail Cornu aspersum: physiological and ecological implications. Can J Zool 88:995-1002. https://doi.org/10.1139/Z10-066

Pokryszko BM (1987) On the aphally in the vertiginidae (Gastropoda: Pulmonata: Orthoneura). J Conchol 32:365-375

Pokryszko BM (1990a) The Vertiginidae of Poland (Gastropoda: Pulmonata: Pupilloidea) a systematic monograph. Ann Zool 43: $133-257$
Pokryszko BM (1990b) Life story and population dynamics of Vertigo pusilla O.F.Müller, 1774 (Gastropoda: Pulmonata: Vertiginidae), with some notes on shell and genital variability. Ann Zool 43:407432

Pokryszko BM (1992) Life history of Vertigo pusilla. Proc Ninth Int Malacol Congress, pp 247-256

Pokryszko BM (1997) Land snail apertural barriers - adaptation or hindrance? (Gastropoda: Pulmonata). Malakol Abh 18:239-248

Pollard E (1975) Aspects of the ecology of Helix pomatia L. J Anim Ecol 44:305-329. https://doi.org/10.2307/3865

Saeki I, Niwa S, Osada N, Hyodo F, Ohta T, Oishi Y, Hiura T (2017) Adaptive significance of arboreality: field evidence from a treeclimbing land snail. Anim Behav 127:53-66

Silva EC, Omenta EP (2014) Population dynamics and reproductive biology of Achatina fulica Bowdich, 1822 (Mollusca, Gastropoda) in Salvador - Bahia. Biota Neotrop 14:1-11. https://doi.org/10.1590/ 1676-0603000414

Tompa AS (1984) Land Snails (Stylommatophora). In: Tompa AS, Verdonk NH, van den Biggelaar JAM (eds) The Mollusca 7. Reproduction. Academic Press, Orlando, San Diego, San Francisco, New York, London, Toronto, Montreal, Sydney, Tokyo, Sao Paulo, pp 47-140

Welter-Schultes F (2012) European non-marine molluscs, a guide for species identification. Planet Poster Editions, Göttingen

Wiktor A (2004) Ślimaki lądowe Polski. Mantis, Olsztyn

Publisher's note Springer Nature remains neutral with regard to jurisdictional claims in published maps and institutional affiliations. 